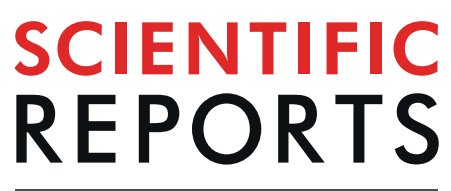

natureresearch

\title{
OPEN Author Correction: Epigenetic patterns associated with an ascidian invasion: a comparison of closely related clades in their native and introduced ranges
}

\author{
Nicola A. Hawes, Achira Amadoru, Louis A. Tremblay, Xavier Pochon, Brendon Dunphy, \\ Andrew E. Fidler \& Kirsty F. Smith
}

Correction to: Scientific Report https://doi.org/10.1038/s41598-019-49813-7, published online 03 October 2019

The original version of this Article contained a typographical error in the spelling of the author Achira Amadoru, which was incorrectly given as Achira Amadorou. This has now been corrected in the PDF and HTML versions of the Article.

(c) (i) Open Access This article is licensed under a Creative Commons Attribution 4.0 International cc. License, which permits use, sharing, adaptation, distribution and reproduction in any medium or format, as long as you give appropriate credit to the original author(s) and the source, provide a link to the Creative Commons license, and indicate if changes were made. The images or other third party material in this article are included in the article's Creative Commons license, unless indicated otherwise in a credit line to the material. If material is not included in the article's Creative Commons license and your intended use is not permitted by statutory regulation or exceeds the permitted use, you will need to obtain permission directly from the copyright holder. To view a copy of this license, visit http://creativecommons.org/licenses/by/4.0/.

(C) The Author(s) 2019 